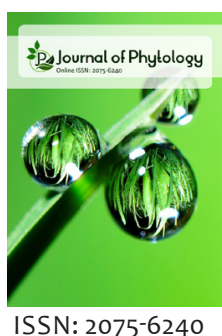

ISSN: $2075-6240$

Received: November 05, 2020

Revised: March 26, 2021

Accepted: March 30, 2021

Published: April 14, 2021

*Corresponding Author:

Milu Herbert,

E-mail: lizamilu1@gmail.com

\section{Halogenation for improvement of seed yield and quality in chilli (Capsicum annuum L.)}

\author{
Milu Herbert*, Dijee Bastian, Rose Mary Francies, K. Anita Cherian, \\ P. Prameela and Riya Mary Mathew \\ Department of Seed Science and Technology, College of Horticulture, Kerala Agricultural University, Thrissur-680656, \\ Kerala, India
}

\begin{abstract}
Freshly harvested seeds of chilli variety Anugraha were treated with halogens namely Calcium oxy chloride $\left(\mathrm{CaOCl}_{2}\right)$ and Iodine crystal $\left(\mathrm{I}_{2}\right)$ indirectly through a carrier Calcium carbonate $\left(\mathrm{CaCO}_{3}\right)$. The treatments included Control (Untreated), $\mathrm{CaOCl}_{2}+\mathrm{CaCO}_{3}$ (2g each $/ \mathrm{kg}$ seed), $\mathrm{CaOCl}_{2}+\mathrm{CaCO}_{3}$ (4g each $/ \mathrm{kg}$ seed), Iodine crystal $+\mathrm{CaCO}_{3}$ $\left(50 \mathrm{mg}\right.$ each $/ \mathrm{kg}$ seed) and Iodine crystal $+\mathrm{CaCO}_{3}\left(100 \mathrm{mg}\right.$ each $/ \mathrm{kg}$ seed). Seed treatment with $\mathrm{CaOCl}_{2}+\mathrm{CaCO}_{3} @ 2 \mathrm{~g}$ each/kg seed registered significantly higher values for fruits per plant, fruit weight, seed yield per plant and hundred seed weight followed by $\mathrm{CaOCl}_{2}+\mathrm{CaCO}_{3} @ 4 \mathrm{~g}$ each $/ \mathrm{kg}$ seed. The treatments, $\mathrm{CaOCl}_{2}+\mathrm{CaCO}_{3} @ 2 \mathrm{~g}$ each $/ \mathrm{kg}$ seed and Iodine crystal + $\mathrm{CaCO}_{3} @ 100 \mathrm{mg}$ each $/ \mathrm{kg}$ seed performed superior in seed quality with higher seedling vigour and lower electrical conductivity of seed leachates over other treatments, while untreated control recorded least seedling vigour indices and highest electrical conductivity.
\end{abstract}

KEYWORDS: Halogens, chlorine, iodine, seed yield, seed quality

\section{INTRODUCTION}

Chilli (Capsicum annuum L.) is extensively cultivated as a vegetable and spice in India. The lion's share in global production of chilli is contributed by India, followed by China. Chilli is a warm season crop. Seeds often germinate slowly in both normal and stress conditions (Demir \& Okcu, 2004). The seeds possess non- starchy endosperm which act as mechanical barrier to growing embryo, affecting germination process. The seeds exhibit dormancy to varying extent causing hindrance to germination, even if they had attained necessary physiological growth to support germination (Patra et al., 2017). Slow germination can lead to susceptibility of seeds and young seedlings to diseases. Thus chilli seed producers may encounter several obstacles owing to slow germination and infection of seeds resulting in reduced seed yield and quality.

Growth and yield attributes of a crop depend largely on the germination and vigour potential of the seeds used for sowing. Seed treatment influence micro environment of each seed and provide opportunity in supplying micro and macro nutrients and also protection of the crop from pests and diseases during the earlier stages. Halogens such as chlorine or iodine used in seed treatment formulations act as free radical quenchers. They act on unsaturated fatty acids in cell membrane, stabilizing carbon to carbon double bonds in the membrane lipids and mitigate the production of free radicals that accelerates ageing process. Besides, their antimicrobial action may account partly for controlling the storage fungi, which is one of the major factors affecting quality of seeds during storage (Hunje et al., 2007), in addition, seed invigoration with halogenation augments productivity in various crops (Vidyadhar \& Singh, 2000).

\section{MATERIALS AND METHODS}

The field experiment was conducted at the Department of Seed Science and Technology, College of Horticulture, Kerala Agricultural University (KAU), Vellanikkara, Thrissur, during July 2019- January 2020. The site is located $40 \mathrm{~m}$ above MSL at $10^{\circ} 54^{\prime} \mathrm{N}$ latitude and $76^{\circ} 28^{\prime} \mathrm{E}$ longitude and experiences humid tropical climate.

Freshly harvested seeds of chilli variety Anugraha were treated with halogens namely Calcium oxy chloride $\left(\mathrm{CaOCl}_{2}\right)$ and Iodine crystal $\left(\mathrm{I}_{2}\right)$ indirectly through a carrier Calcium carbonate $\left(\mathrm{CaCO}_{3}\right)$. The halogen- carrier mixture was prepared by mixing equal quantity of analytical grade halogens and dehydrated calcium carbonate $\left(\mathrm{CaCO}_{3}\right)$. The seeds were then incubated 
with halogen-carrier mixture for five days (Anjalidevi, 1998) so as to impregnate the seeds with halogen. There were five treatments comprising, Control (Untreated), $\mathrm{CaOCl}_{2}+\mathrm{CaCO}_{3}$ ( $2 \mathrm{~g}$ each $/ \mathrm{kg}$ seed), $\mathrm{CaOCl}_{2}+\mathrm{CaCO}_{3}$ (4g each/kg seed), Iodine crystal $+\mathrm{CaCO}_{3}(50 \mathrm{mg}$ each/kg seed) and Iodine crystal + $\mathrm{CaCO}_{3}(100 \mathrm{mg}$ each/kg seed).

The experiment was laid out in a Randomised Block Design (RBD) with four replications for each treatment. After land preparation, the plot was divided into four blocks, each containing five subplots. The plants were spaced $45 \mathrm{~cm} \mathrm{x} 45$ cm apart in an individual subplot. A fertilizer dose of N:P:K@ 75:40:25 Kg/ha respectively was given to the crop and necessary cultural practices were also done throughout the cropping period. Observations on days to first and 50 per cent flowering, plant height, branches per plant, fruits per plant, fruit length, fruit weight, seeds per fruit, seed yield per plant and 100 seed weight were recorded on five randomly selected (tagged) plants in each replication after harvesting and the average was calculated.

The number of days taken from the date of sowing to the emergence of first flower and 50 per cent flowers gave days to first and 50 per cent flowering respectively. The plant height was recorded by measuring the distance from ground level to tip of main shoot using a metre scale. The distance from proximal end to the distal end of the fruit gave the fruit length. Fruit weight was recorded by weighing fresh weight of fruits harvested from the tagged plants using a weighing balance. The average number of seeds per fruit was worked out by counting seeds from five fruits selected randomly from the tagged plants. Weight of seeds extracted from the selected fruits was measured immediately after extraction using digital weighing balance to compute seed yield per plant. Hundred seed weight was recorded by weighing randomly selected hundred seeds from each seed lot.

The experiment for assessing seed quality was laid out in Completely Randomized Block Design (CRD) with the five treatments replicated four times. Seeds obtained from the five treatments of the field experiment were dried separately to a moisture content less than eight per cent and various seed quality parameters such as germination per cent, vigour indices, electrical conductivity of seed leachates and seed moisture content were recorded using the standard procedures.

The results were analysed statistically using Analysis of Variance for Randomised Block Design (RBD) and Completely Randomized Block Design (CRD) and presented in Table 1 and 2 respectively.

\section{RESULTS AND DISCUSSION}

The results on growth and yield parameters (Table 1) revealed that fruits per plant, fruit weight, seed yield per plant and hundred seed weight were significantly influenced by the treatments, while no significant differences were evident in days to first flowering, days to 50 per cent flowering, plant height, branches per plant, fruit length and seeds per fruit.
Among the treatments, $\mathrm{CaOCl}_{2}+\mathrm{CaCO}_{3} @ 2 \mathrm{~g}$ each $/ \mathrm{kg}$ seed recorded higher values for fruits per plant (128.00), fruit weight $(1.56 \mathrm{~g})$ and seed yield per plant $(35.12 \mathrm{~g})$ whereas for hundred seed weight, both the treatments $\mathrm{CaOCl}_{2}+\mathrm{CaCO}_{3} @ 2 \mathrm{~g}$ each $/ \mathrm{kg}$ seed and $\mathrm{CaOCl}_{2}+\mathrm{CaCO}_{3} @ 4 \mathrm{~g}$ each $/ \mathrm{kg}$ seed registered higher value $(0.45 \mathrm{~g})$.

The better performance of $\mathrm{CaOCl}_{2}+\mathrm{CaCO}_{3} @ 2$ g each $/ \mathrm{kg}$ seed and $\mathrm{CaOCl}_{2}+\mathrm{CaCO}_{3} @ 4$ g each $/ \mathrm{kg}$ seed for number of fruits per plant could be due to the positive role of chlorine which performed more or less similar to iodine in seed invigoration, combined with beneficial effects of calcium on growth and yield attributes.

Invigorative action of halogens effect physiological performance in plants leading to positive manifestation in yield attributing characters. Higher fruit weight and seed yield advantage in the treatments $\mathrm{CaOCl}_{2}+\mathrm{CaCO}_{3} @ 2 \mathrm{~g}$ each $/ \mathrm{kg}$ seed and $\mathrm{CaOCl}_{2}+\mathrm{CaCO}_{3} @ 4 \mathrm{~g}$ each $/ \mathrm{kg}$ may be attributed to rapid dry mater accumulation induced by chloride invigoration and its effect on reproductive growth. Higher early seedling vigour and better crop growth induced by halogenation may result in increased rate of photosynthesis and carbohydrate accumulation (Vidyadhar \& Singh, 2000; Narayanan et al., 2011).

The results on quality parameters revealed that there existed significant differences among the treatments for parameters such as seedling shoot length, vigour indices and electrical conductivity of seed leachates while, no significant differences were noticed for germination per cent, seedling root length and seed moisture content (Table 2). The treatments, $\mathrm{CaOCl}_{2}+$ $\mathrm{CaCO}_{3} @ 2$ g each $/ \mathrm{kg}$ seed and Iodine crystal+ $\mathrm{CaCO}_{3} @ 100 \mathrm{mg}$ each/kg seed registered significantly higher seedling shoot length $(5.87 \mathrm{~cm}$ and $5.79 \mathrm{~cm}$ respectively).

Seedling vigour is a physiological condition which depends on quantum of reserve metabolites and activity of enzymes and growth regulators. Since vigour index measure totality of germination and seedling growth, it is considered as a good indicator of seedling vigour. Vigour index I was recorded higher for $\mathrm{CaOCl}_{2}+\mathrm{CaCO}_{3} @ 2$ g each $/ \mathrm{kg}$ seed and Iodine crystal + $\mathrm{CaCO}_{3} @ 100 \mathrm{mg}$ each $/ \mathrm{kg}$ seed (1335 and 1233 respectively) whereas it was least for control (1025). Vigour index II was also found higher for $\mathrm{CaOCl}_{2}+\mathrm{CaCO}_{3} @ 2$ g each $/ \mathrm{kg}$ seed (2079) and Iodine crystal + $\mathrm{CaCO}_{3} @ 100 \mathrm{mg}$ each $/ \mathrm{kg}$ seed (1958), while control recorded the least (1709). Better performance of seeds obtained from halogen treatments might be due to higher initial vigour of the plants induced by the treatments and subsequent accumulation of higher nutrients in seed.

Electrical conductivity of seed leachates is a measure of cell membrane integrity and considered as a good indicator of seed viability. It is negatively correlated with vigour and viability of seeds. High electrical conductivity of seed leachates is an indication of rapid loss of electrolytes such as amino acids and organic acids from seed due to poor integrity of cellular membrane. Better performance of the treatments $\mathrm{CaOCl}_{2}+$ $\mathrm{CaCO}_{3} @ 2$ g each $/ \mathrm{kg}$ seed $\left(1.07 \mathrm{dSm}^{-1}\right)$ and Iodine crystal + $\mathrm{CaCO}_{3} @ 100 \mathrm{mg}$ each $/ \mathrm{kg}$ seed $\left(1.08 \mathrm{dSm}^{-1}\right)$ with lower electrical 
Table 1: Effect of halogenation on growth parameters and seed yield attributes in chilli variety Anugraha

\begin{tabular}{|c|c|c|c|c|c|c|c|c|c|c|}
\hline Treatment & $\begin{array}{l}\text { Days to first } \\
\text { flowering }\end{array}$ & $\begin{array}{l}\text { Days to } 50 \text { per } \\
\text { cent flowering }\end{array}$ & $\begin{array}{c}\text { Plant } \\
\text { height }(\mathrm{cm})\end{array}$ & $\begin{array}{l}\text { Branches } \\
\text { per plant }\end{array}$ & $\begin{array}{c}\text { Fruits } \\
\text { per plant }\end{array}$ & $\begin{array}{c}\text { Fruit } \\
\text { length }(\mathrm{cm})\end{array}$ & $\begin{array}{c}\text { Fruit } \\
\text { weight }(\mathrm{g})\end{array}$ & $\begin{array}{c}\text { Seeds } \\
\text { per fruit }\end{array}$ & $\begin{array}{l}\text { Seed yield } \\
\text { per plant }(\mathrm{g})\end{array}$ & $\begin{array}{c}100 \text { seed } \\
\text { weight }(g)\end{array}$ \\
\hline Control & 63.50 & 68.00 & 53.80 & 32.82 & $84.75^{c}$ & 6.05 & $1.04^{d}$ & 53.00 & $17.96^{d}$ & $0.40^{b}$ \\
\hline $\mathrm{CaOCl}_{2}+\mathrm{CaCO}_{3}(2 \mathrm{~g})$ & 63.00 & 66.25 & 57.92 & 33.37 & $128.00^{\mathrm{a}}$ & 6.41 & $1.56^{\mathrm{a}}$ & 61.00 & $35.12^{\mathrm{a}}$ & $0.45^{a}$ \\
\hline $\mathrm{CaOCl}_{2}^{2}+\mathrm{CaCO}_{3}^{3}(4 \mathrm{~g})$ & 62.00 & 64.25 & 53.54 & 34.25 & $126.25^{\mathrm{a}}$ & 6.45 & $1.44^{\mathrm{b}}$ & 58.25 & $33.10^{\mathrm{a}}$ & $0.45^{\mathrm{a}}$ \\
\hline Iodine ${ }^{2}+\mathrm{CaCO}_{3}^{3}(50 \mathrm{mg})$ & 62.25 & 67.25 & 52.45 & 33.31 & $94.50^{\mathrm{b}}$ & 6.88 & $1.07^{\mathrm{cd}}$ & 58.25 & $22.12^{c}$ & $0.40^{\mathrm{b}}$ \\
\hline Iodine $+\mathrm{CaCO}_{3}^{3}(100 \mathrm{mg})$ & 62.75 & 66.25 & 59.06 & 33.50 & $124.25^{\mathrm{a}}$ & 6.80 & $1.13^{c}$ & 55.75 & $28.41^{b}$ & $0.41^{b}$ \\
\hline SEm & 3.89 & 9.61 & 21.99 & 3.09 & 15.29 & 0.48 & 0.00 & 11.60 & 1.87 & 0.00 \\
\hline$C D(0.05)$ & NS & NS & NS & NS & 6.02 & NS & 0.07 & NS & 2.11 & 0.02 \\
\hline
\end{tabular}

Table 2: Effect of halogenation on seed quality parameters in chilli variety Anugraha

\begin{tabular}{|c|c|c|c|c|c|c|c|c|}
\hline Treatment & $\begin{array}{l}\text { Germination } \\
\text { per cent (\%) }\end{array}$ & $\begin{array}{c}\text { Shoot } \\
\text { length }(\mathrm{cm})\end{array}$ & $\begin{array}{c}\text { Root } \\
\text { length }(\mathrm{cm})\end{array}$ & $\begin{array}{l}\text { Vigour } \\
\text { Index I }\end{array}$ & $\begin{array}{c}\text { Dry } \\
\text { weight (mg) }\end{array}$ & $\begin{array}{l}\text { Vigour } \\
\text { Index II }\end{array}$ & $\begin{array}{c}\text { Electrical } \\
\text { conductivity }\left(\mathrm{dSm}^{-1}\right)\end{array}$ & $\begin{array}{c}\text { Moisture } \\
\text { per } \\
\text { cent (\%) }\end{array}$ \\
\hline Control & $71.25(57.64)$ & $5.33^{c}$ & 9.07 & $1025^{c}$ & 24.00 & $1709^{c}$ & $1.23^{\mathrm{a}}$ & 6.72 \\
\hline $\mathrm{CaOCl}_{2}+\mathrm{CaCO}_{3}(2 \mathrm{~g})$ & $85.25(67.91)$ & $5.87^{a}$ & 9.78 & $1335^{\mathrm{a}}$ & 24.40 & $2079^{a}$ & $1.07^{d}$ & 6.32 \\
\hline $\mathrm{CaOCl}_{2}^{2}+\mathrm{CaCO}_{3}^{3}(4 \mathrm{~g})$ & $74.5(59.80)$ & $5.45^{b c}$ & 9.36 & $1103^{b c}$ & 24.05 & $1792^{b c}$ & $1.15^{\mathrm{bc}}$ & 6.45 \\
\hline Iodine $+\mathrm{CaCO}_{3}$ (50mg) & $79.25(63.05)$ & $5.39^{c}$ & 9.42 & $1171^{\mathrm{b}}$ & 24.32 & $1928^{a b c}$ & $1.17^{\mathrm{ab}}$ & 6.55 \\
\hline Iodine $+\mathrm{CaCO}_{3}(100 \mathrm{mg})$ & $80.50(64.20)$ & $5.79^{a b}$ & 9.53 & $1233^{a b}$ & 24.35 & $1958^{\mathrm{ab}}$ & $1.08^{\mathrm{cd}}$ & 6.40 \\
\hline SEm & 24.71 & 0.06 & 0.20 & 8855.84 & 0.13 & 23303.29 & 0.00 & 0.17 \\
\hline$C D(0.05)$ & NS & 0.37 & NS & 141.80 & NS & 230.02 & 0.07 & NS \\
\hline
\end{tabular}

*Figures in parentheses are arc-sine transformed values

conductivity may be accounted for enhanced seed quality and lower pathogenicity rendering cell membrane integrity resulting from the carry over effect of halogenation.

\section{CONCLUSION}

Many of the recommended seed treatments are not popular among small and marginal farmers because of difficulty in adoption of the treatments or non-availability or expensive nature of treatment materials. Seed treatment with halogen is easy adoptable as it can be done along with routine post- harvest handling of seeds. Halogen treatment should be considered as a best methodology since it demands lesser input cost.

Even though seed treatment with $\mathrm{CaOCl}_{2}+\mathrm{CaCO}_{3} @ 4 \mathrm{~g}$ each $/ \mathrm{kg}$ seed was found best in improving growth and seed yield attributes, it could record only lower germination per cent and vigour indices in comparison with $\mathrm{CaOCl}_{2}+\mathrm{CaCO}_{3}$ $@ 2$ g each $/ \mathrm{kg}$ seed Iodine crystal $+\mathrm{CaCO}_{3} @ 100 \mathrm{mg}$ each $/ \mathrm{kg}$ seed. Seed treatment with $\mathrm{CaOCl}_{2}+\mathrm{CaCO}_{3} @ 2$ g each $/ \mathrm{kg}$ seed was found to have multiple benefits of enhancement of growth and seed yield parameters and maintenance of seed quality.

As chlorine is more reactive than iodine, its beneficial effect when used as seed treatment is more pronounced even at lower doses. Moreover, bleaching powder and calcium carbonate are easily available and less expensive. Hence, seed treatment with $\mathrm{CaOCl}_{2}+\mathrm{CaCO}_{3} @ 2 \mathrm{~g}$ each $/ \mathrm{kg}$ seed can be recommended to improve seed yield and quality in chilli as it is a simple and cost effective treatment which can be easily adopted by both large and small scale farmers.

\section{REFERENCES}

Anjalidevi, R. K. (1998). Studies on halogenation of cotton seeds to prolong the shelf life and its resultant effect on productivity. M.Sc. (Ag) thesis, Tamil Nadu Agricultural University, Coimbatore, 112p.

Demir, I., \& Okcu, G. (2004). Aerated hydration treatment for improved germination and seedling growth in aubergine (Solarium melongena) and pepper (Capsicum annuum). Annals of Applied Biology, 144, 121 123. https://doi.org/10.1111/j.1744-7348.2004.tb00324.x

Hunje, R., Vyakarnahal, B. S., \& Jagadeesh, R. C. (2007). Studies on Halogenation and Plant Bio - products on Storability of Chilli Seed. Karnataka Journal of Agricultural Science, 20(3), 506-510.

Narayanan, S. G., Prakash M., \& Kumar, B. S. (2011). Seed enhancement techniques to improve productivity of certain oilseed crops. Global Journal of Plant Ecophysiology, 1(1), 1-13.

Patra, C., Sahoo, L., \& Mohanty, S. K. (2017). Dormancy behaviour of developing seeds in different genotypes of chilli (capsicum annuum L.). International Journal of Science Environment and Technology, 6(1), 90-94.

Vidyadhar, B., \& Singh, B. G. (2000). Effect of seed treatment with halogens on yield and yield attributes in maize hybrid $\mathrm{BH}-1001$. Indian Journal of Plant Physiology, 5, 385-386. 